\title{
Hanford Site Implementation of the National Environmental Policy Act: Activities Tracking
}

\author{
M. H. Killinger
}

K. B. Selby

June 1989

Prepared for the U.S. Department of Energy under Contract DE-AC06-76RLO 1830

Pacific Northwest Laboratory Operated for the U.S. Department of Energy by Battelle Memorial Institute 


\title{
DISCLAIMER
}

This program was prepared as an account of work sponsored by an agency of the United States Government. Neither the United States Government nor any agency thereof, nor Battelle Memorial Institute, nor any of their employees, makes any warranty, express or implied, or assumes any legal liability or responsibility for the accuracy, completeness, or usefulness of any information, apparatus, product, or process disclosed, or represents that its use would not infringe privately owned rights. Reference herein to any specific commerical product, process, or service by trade name, trademark, manufacturer, or otherwise, does not necessarily constitute or imply its endorsement, recommendation, or favoring by the United States Government or any agency thereof, or Battelle Memorial Institute. The views and opinions of authors expressed herein do not necessarily state or reflect those of the United States Government or any agency thereof.

\author{
PACIFIC NORTHWEST LABORATORY \\ operated by \\ BATTELLE MEMORIAL INSTITUTE \\ for the \\ UNITED STATES DEPARTMENT OF ENERGY \\ under Contract DE-ACO6-76RLO 1830
}

\author{
Printed in the United States of America \\ Available from \\ National Technical Information Service \\ United States Department of Commerce \\ 5285 Port Royal Road \\ Springfield, Virginia 22161 \\ NTIS Price Codes \\ Microfiche $\mathrm{AO1}$ \\ Printed Copy
}

$\begin{array}{cc}\text { Pages } & \begin{array}{c}\text { Price } \\ \text { Codes }\end{array} \\ 001-025 & \text { A02 } \\ 026-050 & \text { A03 } \\ 051-075 & \text { A04 } \\ 076-100 & \text { A05 } \\ 101-125 & \text { A06 } \\ 126-150 & \text { A07 } \\ 151-175 & \text { A08 } \\ 176-200 & \text { A09 } \\ 201-225 & \text { A10 } \\ 226-250 & \text { A11 } \\ 251-275 & \text { A12 } \\ 276-300 & \text { A13 }\end{array}$


PNL -6955

UC -630

HANFORD SITE IMPLEMENTATION OF THE NATIONAL ENVIRONMENTAL POLICY ACT: ACTIVITIES TRACKING

M. H. Killinger

K. B. Selby

June 1989

Prepared for the U.S. Department of Energy under Contract DE-AC06-76RLO 1830

Pacific Northwest Laboratory

Richland, Washington 99352 


\section{FOREWORD}

This report has been prepared in support of the environmental policy of the U.S. Department of Energy (DOE), as set forth in DOE Notice 5400.3, "Environmental Policy Statement."(a) This notice states that it is DOE's policy to conduct its activities in an environmentally safe and sound manner. Further, it is also the policy of DOE to conduct its operations in accordance with the letter and spirit of applicable environmental statutes, regulations, and standards. The subject of this report, the National Environmental Policy Act (NEPA), is one of the applicable federal environmental statutes for Hanford Site activities.

(a) The directive expired July 1, 1988; however, a DOE headquarters message states that the policy remains in effect until a replacement is issued. 



\section{$\underline{\text { SUMMARY }}$}

The National Environmental Policy Act (NEPA) environmental review process is mandatory for federal agencies. This report, which was prepared by Pacific Northwest Laboratory (PNL), (a) provides the DOE Richland Operations Office (DOE-RL) and the Hanford contractors with a method for tracking, integrating, and coordinating NEPA compliance activities at the Hanford Site.

The environmental review process is briefly described and illustrated in a flow chart. The report then explains a method for developing project timecharts that show when documents or decision points were completed or are projected to be completed. The tracking system has been automated and placed on the Hanford Local Area Network (HLAN). Time schedules for many Hanford projects are available for viewing. Access commands and the password can be obtained from Mark Killinger of PNL's Technology Policy Analys is Section (376-4249) or Paul Dunigan of DOE-RL's Safety and Environmental Division (376-6667).

(a) Pacific Northwest Laboratory is operated for the U.S. Department of Energy by Battelle Memorial Institute under Contract DE-AC06-76RLO 1830. 



\section{CONTENTS}

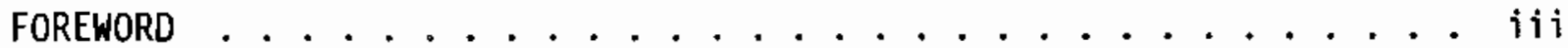

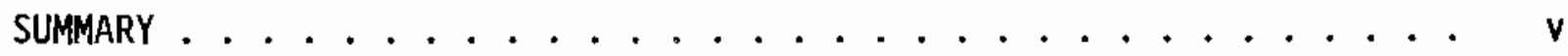

LIST OF ACRONYMS ........................ ix

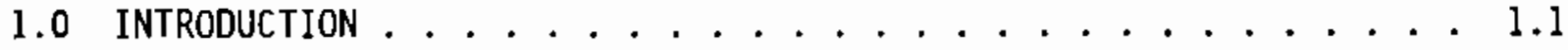

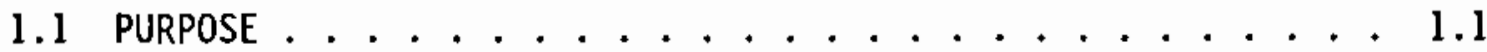

1.2 CONTENTS OF REPORT . . . . . . . . . . . 1.2

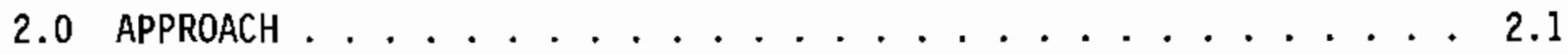

2.1 THE DOE NEPA PROCESS ................ 2.1

2.2 METHODOLOGY FOR PREPARING PROJECT TIMECHARTS . . . . . . 2.4

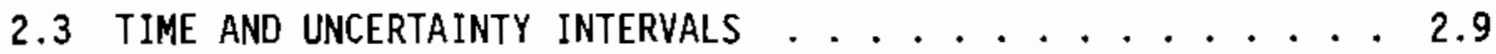

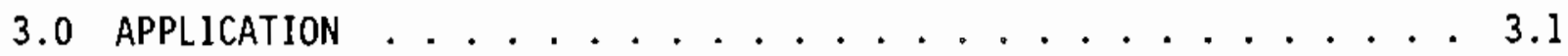

3.1 SELECTION OF PROJECTS AND ACTIVITIES
FOR INCLUSION IN THE TRACKING SYSTEM $\ldots \ldots \ldots \ldots . \ldots . \ldots . \ldots$

3.2 EXAMPLE TIMECHARTS . . . . . . . . . . . 3.2

3.2.1 Example Individual Project Timechart . . . . . 3.2

3.2.2 Conceptual Integrated Timechart . . . . . . . 3.4

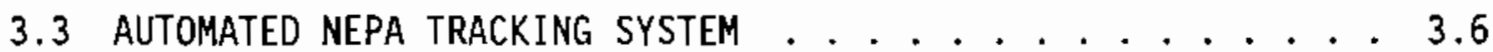

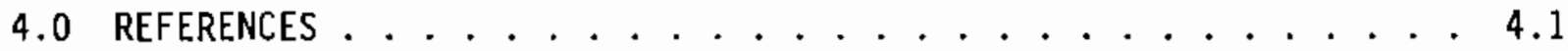

APPENDIX A - TIME AND UNCERTAINTY INTERVALS . . . . . . . . A.1 


\section{FIGURES}

2.1 Generic Environmental Review Flowchart (GERF) . . . . . . . 2.2 2.2 Blank Survey Form ................. 2.5

2.3 Generic EIS Timechart (GET). . . . . . . . . . . . 2.8

3.1 Surplus Production Reactors Decommissioning Timechart . . . . . 3.3

3.2 Conceptual Integrated Timechart . . . . . . . . . 3.5

3.3 Time Schedule from Automated Tracking System . . . . . . . . 3.7 


\section{LIST OF ACRONYMS}

$\begin{array}{ll}\text { ADM } & \text { Action Description Memorandum } \\ \text { CERCLA } & \text { Comprehensive Environmental Response Compensation and Liability Act } \\ \text { DEIS } & \text { Draft Environmental Impact Statement } \\ \text { DOE-HQ } & \text { Department of Energy Headquarters } \\ \text { DOE-RL } & \text { Department of Energy, Richland Operations Office } \\ \text { EA } & \text { Environmental Assessment } \\ \text { EE } & \text { Environmental Evaluation } \\ \text { EIS } & \text { Environmental Impact Statement } \\ \text { FEIS } & \text { Final Environmental Impact Statement } \\ \text { FONSI } & \text { Finding of No Significant Impact } \\ \text { FR } & \text { Federal Register } \\ \text { GET } & \text { Generic EIS Timechart } \\ \text { GERF } & \text { Generic Environmental Review Flowchart } \\ \text { HLAN } & \text { Hanford Local Area Network } \\ \text { MTF } & \text { Memorandum to File } \\ \text { NEPA } & \text { National Environmental Policy Act } \\ \text { NOI } & \text { Notice of Intent } \\ \text { PNL } & \text { Pacific Northwest Laboratory } \\ \text { ROD } & \text { Record of Decision } \\ \text { SPRD } & \text { Surplus Production Reactors Decommissioning } \\ \text { TQ } & \text { Threshold Question } \\ \text { TRU } & \text { Transuranic waste }\end{array}$





\subsection{INTRODUCTION}

This report, prepared by Pacific Northwest Laboratory, describes a method for tracking the environmental review process for current or proposed activities on the Hanford Site. It is a companion report to Guidelines for Hanford Site Implementation of the National Environmental Policy Act (King, 1989). King's document describes Hanford's environmental review process under the National Environmental Policy Act (NEPA). This report provides the foundation for applying that process to specific activities at the Hanford Site.

\subsection{PURPOSE}

The purpose of this report is to provide DOE Richland Operations (DOE$\mathrm{RL}$ ) and the Hanford contractors with a method for tracking, integrating, and coordinating NEPA compliance activities at the Hanford site. The implementation of this system will provide the basis for a consistent approach to planning environmental reviews, will ensure the necessary scheduling and tracking of the NEPA process for all affected Hanford projects and activities, and will enhance communication among technical staff and managers responsible for environmental review activities.

It is important for planning purposes to have a comprehensive view of Hanford activities that may require preparation of environmental documentation related to NEPA. For example, planners need to know when NEPA-related decisions will be required, such as whether an Environmental Impact Statement (EIS) is necessary or which of the alternative actions discussed in an EIS should be selected. It is valuable for project managers and DOE to know when resources must be available for preparing and reviewing environmental documentation. The tracking system described in this report provides this information.

Several current and proposed Hanford Site activities require or may require NEPA documentation [e.g., an Environmental Assessment (EA) or an EIS]. To assist DOE in deciding whether an EA or EIS is necessary, other environmental documentation may be prepared, including an Environmental 
Evaluation (EE) ${ }^{(a)}$ or an Action Description Memorandum (ADM). To document NEPA-related decisions, the Memorandum to File (MTF), Finding of No Significant Impact (FONSI), and Record of Decision (ROD) are used. This report refers to all these documents collectively as "environmental documentation" and the process of preparing them as the "environmental review process." It should be noted that the ADM and the MTF are not actual NEPA documents but are instead DOE (RL and $H Q$ ) documents designed to aid the environmental review process.

This report describes a method for tracking the environmental review process for current and proposed projects on the Hanford Site. This method involves identifying the projects, determining where they currently are in the environmental review process, and projecting schedules for future action or decision points. The report also shows how the time frames for all of these projects may be integrated to depict the extent of NEPA activity expected for the entire Hanford Site at any given time. The method has been implemented for several projects on the Hanford Site, as described in Chapters 2 and 3.

\subsection{CONTENTS OF REPORT}

The approach taken in developing this tracking method is described in Chapter 2. The environmental review process is recounted and illustrated in a flow chart that is used in developing project timecharts. The time required to complete each step of the process is estimated, based on past experience at the Hanford Site and discussion with knowledgeable PNL personnel. Chapter 3 describes the application of the tracking method to several current projects or actions on the Hanford Site. This section al so describes how the tracking system has been automated to make it available to everyone on the Hanford Local Area Network (HLAN). Finally, future efforts are discussed.

(a) The EE is a DOE-RL document only. It is not a NEPA document nor is it a DOE-HQ document (DOE-RL 1987). 


\subsection{APPROACH}

This chapter presents a generic flowchart of the DOE NEPA process. The development of Hanford project timecharts is also described. These timecharts follow the steps of the generic flowchart.

\subsection{THE DOE NEPA PROCESS}

The environmental review process for compliance with NEPA on the Hanford Site is described in detail in King (1989). Other references for the following discussion are DOE (1987), DOE-RL (1987), and CEQ (1986). This process can be segmented into specific steps. Figure 2.1, a flowchart of the major decision and action points encountered during the environmental review process, depicts these steps. This flowchart, referred to as the Generic Environmental Review Flowchart (GERF), is related to the project timecharts discussed in Section 3. The GERF shows various routes typically taken throughout the environmental review process. The letters in the boxes match the letters written in brackets below. The following is an explanation of the flowchart.

\section{[A] Identify action.}

[B] Does the action fall under a categorical exclusion? Is the proposed action categorically excluded from the requirement for NEPA documentation because it is so listed in Section D of the 1987 "DOE NEPA Guidelines"?

Yes. The decision is documented in a memorandum similar to an MTF [C]. For simplicity, step [C] in Figure 2.1 is labeled MTF. Action may begin. This is defined as Route 1.

No; it is immediately evident that an EIS is necessary because it is listed in Section D of DOE (1987) as "normally requiring an EIS." An $A D M$ is prepared [D], notifying DOE-HQ that an EIS is required. The EIS is prepared [E] and an ROD is issued [F] based on the EIS. DOE-RL then carries out the ROD provisions. This is defined as Route 7. Not shown 


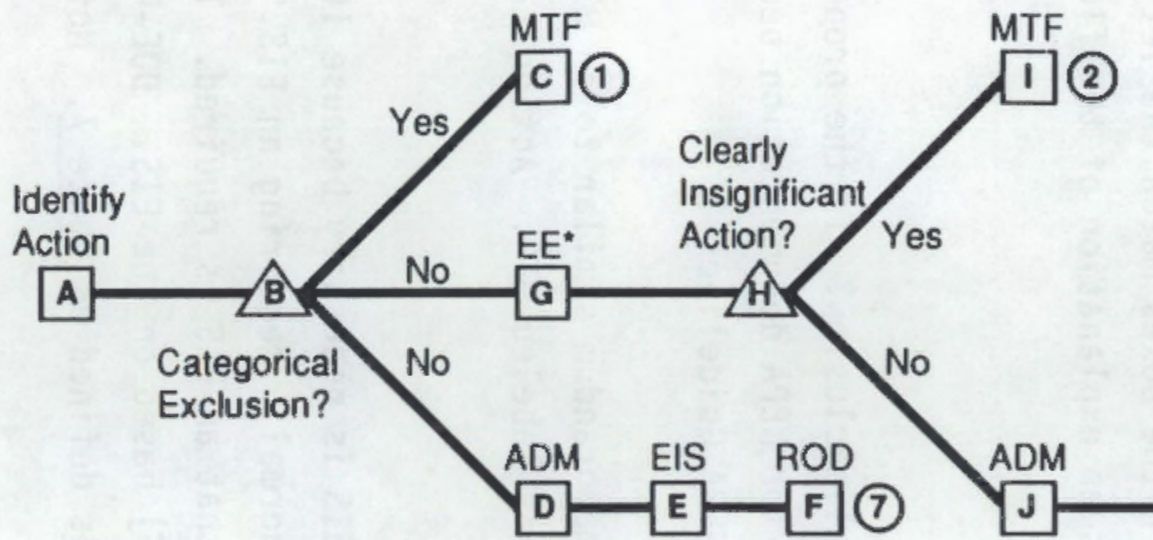

$$
\begin{array}{ll}
\text { ADM } & =\text { Action Description Memorandum } \\
\text { EA } & =\text { Environmental Assessment } \\
\text { EE } & =\text { Environmental Evaluation* } \\
\text { EIS } & =\text { Environmental Impact Statement } \\
\text { FONSI } & =\text { Finding of No Significant Impact } \\
\text { MTF } & =\text { Memorandum to File } \\
\text { ROD } & =\text { Record of Decision } \\
\text { TQ } & =\text { Threshold Question }
\end{array}
$$

*The Environmental Evaluation (EE) is a DOE-RL document only. It is not a NEPA

document nor a DOE-HQ document.

$$
\begin{aligned}
& \text { (1) - Categorical Exclusion } \\
& \text { (2) - Clearly insignificant Action } \\
& \text { (3) }-A D M \\
& \text { (4) - ADM/EA } \\
& \text { (5) }-A D M / E I S \\
& \text { (5) - ADM/EAEIS } \\
& \text { (7) - EIS }
\end{aligned}
$$


on the GERF, yet still possible, is a route (similar to route 7 ) in which an ADM notifies DOE-HQ that an EA is required because the action is listed in Section D of DOE (1987) as "normally requiring an EA but not necessarily an EIS." The EA is prepared, resulting in either a FONSI or an EIS. This route was not shown so as to make the GERF less confusing.

No; but it is not clear whether an EIS is necessary. Go to step [G] of Figure 2.1.

[G] Prepare Environmental Evaluation (EE). The EE is a document mandated by DOE-RL only. It is relatively brief and consists of a checklist and text to help determine the environmental effects of the proposed activity and the significance of these effects. It may be initiated as early as immediately after the action is identified. It is normally finalized only if an ADM is not prepared, i.e., it becomes a supporting document to the MTF (step [I]).

[H] Clearly insignificant action? DOE answers this question based on the information in the EE.

Yes. This is documented in an MTF [I]. MTF decisions are sometimes made by DOE-HQ (as in Office of Nuclear Energy activities) and sometimes the authority is delegated to DOE-RL (as in Office of Defense Programs activities). Action may begin. This is defined as Route 2.

No. Go to step [J] of Figure 2.1.

[J] Prepare Action Description Memorandum (ADM). The ADM contains a concise description of the proposed action and its location and an identification of potential issues. The ADM is usually completed by the contractor and submitted to DOE-RL who then submits it with an RL recommendation to DOE-HQ.

[K] Threshold Question (TQ). Is this a major federal action with significant environmental effects? This question is ultimately answered by DOE-HQ based on the information in the ADM. 
No. This means that neither an EA nor an EIS is required. This is documented in an MTF [L]. Action may begin. This is defined as Route 3.

Yes. This means that an EIS is required. An EIS is prepared [M], an ROD is issued [N] based on the EIS, and DOE-RL carries out the ROD provisions. This is defined as Route 5 .

Uncertain. DOE-RL initiates an Environmental Assessment (EA). The EA $[P]$ is intended to gather information to resolve the question of whether the proposed action is expected to have significant environmental effects. The EA is submitted to DOE-HQ. Go to step [Q] of Figure 2.1.

[Q] Threshold Question (TQ). Is this a major federal action with significant environmental effects? DOE-HQ answers this based on the EA.

No. A Finding of No Significant Impact (FONSI) is prepared by DOE [R]. A 30-day public review period may be required [depending on analysis of the criteria found in question 37b of CEQ's " 40 most-asked questions" concerning NEPA implementing regulations (46 FR 18026-18038, March 23, 1981)]. Action may then begin. This is defined as Route 4.

Yes. DOE-RL is notified that an EIS is required. An EIS is prepared [S], an ROD is issued [T] based on the EIS, and DOE-RL carries out the ROD provisions. This is defined as Route 6.

\subsection{METHODOLOGY FOR PREPARING PROJECT TIMECHARTS}

The first step in developing the tracking method was to define a means for acquiring information. A survey (see Figure 2.2) was developed for obtaining information on each project from cognizant project or program personnel. The information from the survey was used to determine the status of the project, what environmental documentation had already been completed, and what documentation was expected to be completed in the future. 
PROJECT NAME:

CONTACT :

DATE :

A. General information on the project:

1. Current status of the project (i.e., at what point are you in the process of planning, design, construction, or other action?).

2. a) What is the proposed future schedule? b) What could happen to significantly change that schedule?

3. Are there other projects (completed or currently in progress) on the Hanford Site that are related to this project?

B. NEPA-related information on the project:

1. a) What NEPA or other environmental documentation has already been prepared? (e.g., Environmental Evaluation, Action Description Memorandum, Environmental Assessment, Finding of No Significant Impact, Environmental Impact Statement, Memorandum to File)? b) Is there a need to revisit this documentation or prepare additional documentation before construction/action?

2. What other supporting/related documents exist that address environmental impacts?

FIGURE 2.2. Blank Survey Form 
3. a) Are there any plans for preparing NEPA or other environmental documentation? b) What is the planned schedule, if any? c) What could happen to significantly change that schedule?

4. Are there interrelationships with other projects that have implications on the preparation of NEPA documentation? For example, could documentation for another project have implications for your project or be used in preparing NEPA documentation for your project?

5. Is the preparation of NEPA documentation on the critical path for your project's development? That is, is it holding things up because you can't proceed until certain documentation is completed?

Additional comments:

FIGURE 2.2. (cont'd) 
A timechart for each project was then developed utilizing this information. Boxes on these timecharts indicate points in time when process steps are begun or ended, or when decision points are reached. Steps or decision points that were completed most recently are placed at the beginning of the time chart (as an example, see Figure 3.1 on page 3.3 ). The most recently completed step is associated with the appropriate month and year on the horizontal axis. Future steps are then projected along the time line, using estimated time intervals to complete each step (these time intervals are explained in Section 2.3). This continues until either the environmental review process is completed, or a decision point is reached where alternative routes may be taken. In the latter case, diagonal lines branching out from the decision point (such as a threshold question) indicate the alternative routes that could be taken, depending on the decision made. If a threshold question is answered "yes," the chart refers the reader to Figure 2.3, the Generic EIS Timechart (GET), which shows the typical detailed time schedule for producing an EIS. Referring to the GET is simpler than trying to place the complete time schedules for all the alternative routes on one timechart. The GET is basically an extension of the project timechart.

Because some process steps have little time separating them, and because of uncertainty intervals (to be explained below), crowding would occur if all points were placed on the same horizontal time line (see Figure 2.3). For this reason, time points (indicated by boxes) are staggered up the page. After going up the page, the next box may drop down again to the bottom if there is sufficient room. In all cases, the charts are to be read from left to right, although steps may also be moving up the page. For clarity, boxes are numbered chronologically, indicating their sequence in time. These numbers have no relationship to route numbers or number of months.

Because the time to complete each step of the environmental review process varies, uncertainty intervals are placed on either side of boxes. Each process step has an uncertainty interval of plus or minus a certain number of months that is associated with the estimated time to complete that process step. For example, an EA is estimated to take six months to complete, plus or minus three months. That is, it could take from three to nine months (or even longer in some cases), depending on the complexity of the proposal, variability of 


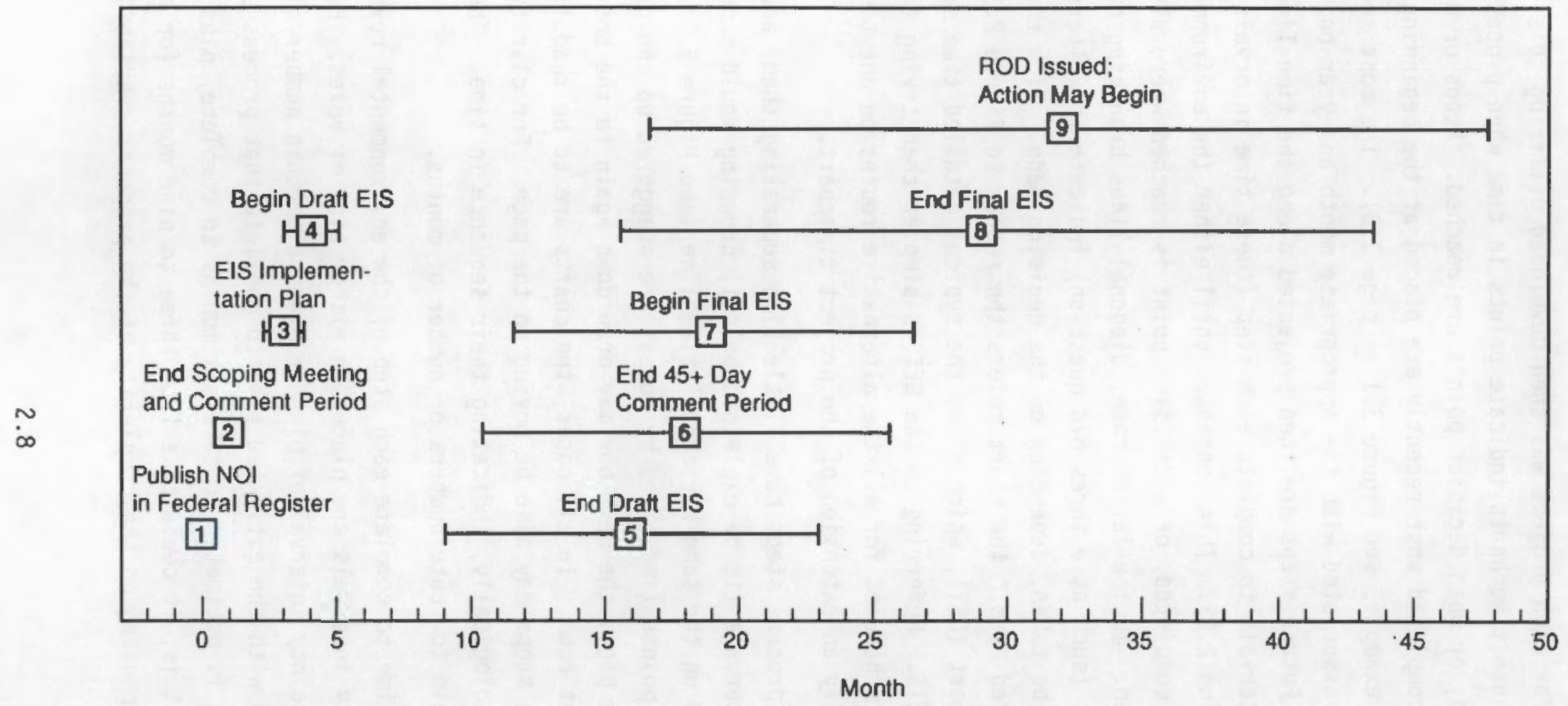

FIGURE 2.3. Generic EIS Timechart (GET) 
review times, and other factors. The uncertainty intervals are cumulative with time. Thus, if a given time point (i.e., box) has an uncertainty interval of \pm 2 months, and the next process step has an associated uncertainty of \pm 4 months, the uncertainty interval for the second time point would be $2+4=$ * 6 months. Each sequential uncertainty interval will therefore increase by the amount of uncertainty associated with the last process step.

\subsection{TIME AND UNCERTAINTY INTERVALS}

A table of time and uncertainty intervals for each step in the environmental review process was prepared for each of the seven routes defined in Section 2.1 and shown on the GERF (Figure 2.1). These seven tables are in Appendix A. The times are based on past Hanford Site experience and discussions with knowledgeable PNL personnel. Each table starts at "Identify Action" and ends with "Action May Begin" or "ROD issued; implement decision." The tables are consistent with the GERF; the only difference is that the EIS process, when included in a table, contains detail not included in the GERF. In the tables, answers to questions and other determinations (e.g., the threshold question) are given in brackets.

Sometimes the time intervals actually used on the timecharts differ somewhat from the tables in Appendix A. This is because some projects are in the midst of preparing a document for which a completion schedule has already been established by the personnel involved. In those cases, their projections are used for the timechart. There may also be projects that have special deadlines to be met, resulting in certain requirements on the completion of environmental documentation. 



\subsection{APPLICATION}

This chapter outlines the criteria used in selecting projects and activities for inclusion in the NEPA tracking system. Example timecharts are then presented. Finally, the automated NEPA tracking system is described.

\subsection{SELECTION OF PROJECTS AND ACTIVITIES FOR INCLUSION IN THE TRACKING SYSTEM}

The following criteria were developed to determine whether a project should be included in the tracking system:

- the effect on human health and safety

- unique characteristics of the geographic area:

- proximity to historic or cultural resources (including sites on or eligible for the National Register of Historic Places). Sensitive areas include the Columbia River shoreline and its islands, Gable Mountain, Gable Butte, and Rattlesnake Springs.

- wetlands (Rattlesnake Springs and others)

- 500-year floodplain

- ecologically critical areas (including portions of the Arid Lands Ecology Reserve, among others), particularly if action involves disturbance of threatened or endangered species or removal of habitat

- recreational areas (Columbia River)

- whether there is a significant discharge or deposit of waste effluents (including thermal and noise) to air, soil, surface water, or groundwater

- whether the effects of the action are likely to be highly controversial

- whether the action may establish a precedent for future actions with significant effects or a decision in principle about a future consideration

- whether the action, though insignificant, is related to other actions in a way that will cause cumulatively significant impacts

- whether the action threatens a violation of federal, state, or local law or requirements imposed for environmental protection 
- whether the project is relatively large and expensive (i.e., in the millions of dollars).

Based on the criteria above and information received to date from project contacts, many projects and activities have been selected and placed in the tracking system. Generally, the projects are significant enough to have a potential of requiring an EA or EIS. Information on additional projects and activities will continue to be collected. Those projects selected for inclusion in the tracking system will be added as a part of future efforts.

\subsection{EXAMPLE TIMECHARTS}

This section contains an example project timechart and a conceptual integrated timechart. Although timecharts have been developed for many projects and actions, only one has been used as an illustration because the timecharts require frequent updating and, thus, would be outdated soon after publication of this report. Timecharts for all the projects have been converted onto the Automated NEPA Tracking System, which is discussed in Section 3.3.

\subsubsection{Example Individual Project Timechart}

Steps in the project timecharts are numbered chronologically, while those in the GERF are designated by letters. The timecharts are intended to be used as guidelines for planning the environmental review process. Because there is great variability in review/revision times, printing/distribution times, and other steps in the environmental review process, there is no implied requirement that a specific project meet the projected decision points or completion times shown on its timechart. The time periods shown to complete the various steps are estimates based on information from project contacts or based on experience at the Hanford Site.

As an example, the project timechart for the Surplus Production Reactors Decommissioning (SPRD) is presented in Figure 3.1. This project is following Route 7 on the GERF (Figure 2.1 on page 2.2), and is currently at step E. It has already been decided that an EIS would be prepared for this action, so 


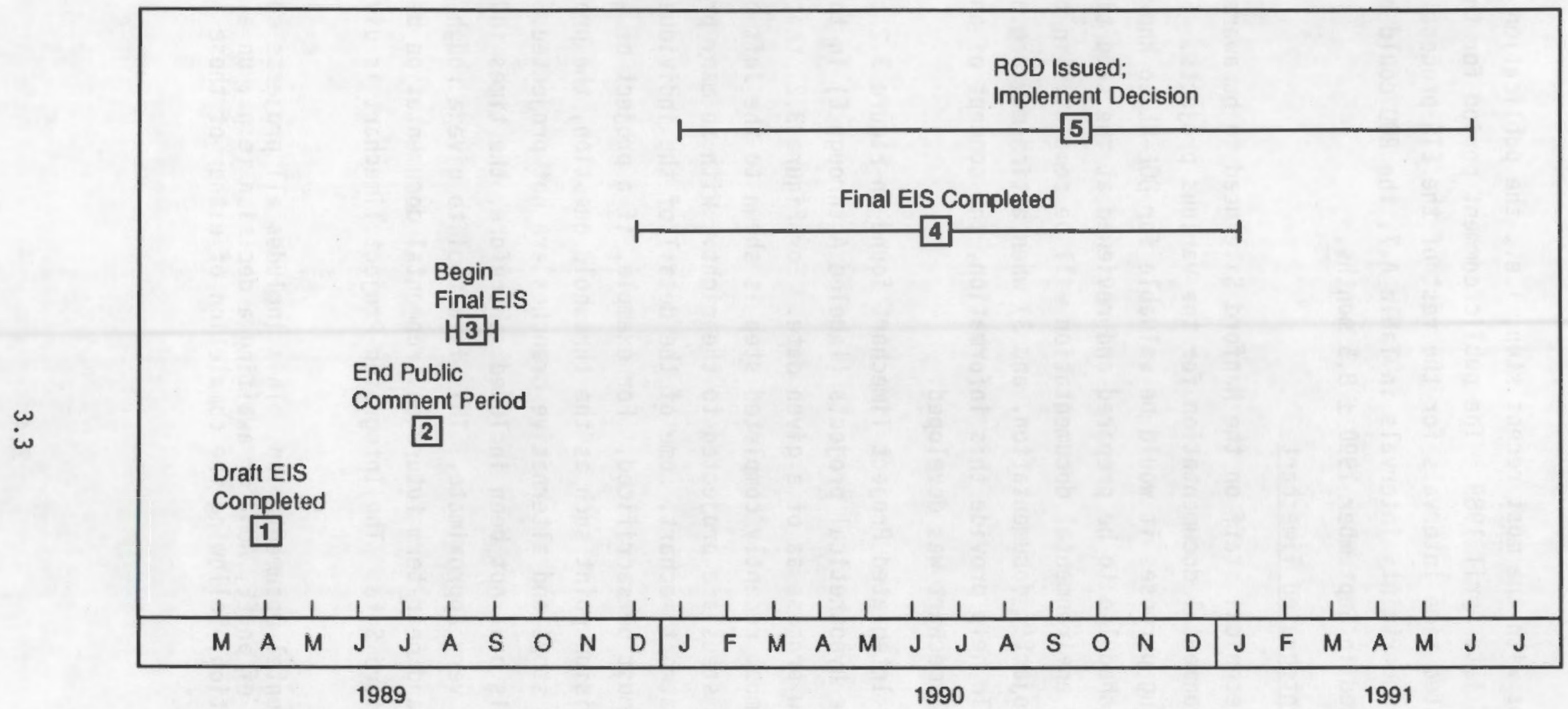

FIGURE 3.1. Surplus Production Reactors Decommissioning (SPRD) 
the timechart begins with the most recent step, i.e., the publication of the draft EIS (DEIS) in late April 1989. The public comment period for this DEIS is 90 days. Estimated time intervals for the rest of the EIS process follow. Using the time and uncertainty intervals in Table A.7, the ROD could be expected to be issued in September $1990 \pm 8.5$ months.

\subsubsection{Conceptual Integrated Timechart}

Managers and technical staff on the Hanford Site need to be aware of the schedules for environmental documentation for the various projects. For example, for planning purposes it would be valuable for DOE-RL to know 1) if multiple EISs are scheduled to be prepared and reviewed at the same time, 2) if a given piece of environmental documentation will be completed in time for use in a related project's documentation, and 3) when action may begin on related projects. To help provide this information, the concept of an Integrated Project Timechart was developed.

The conceptual Integrated Project Timechart found in Figure 3.2 shows the position of five hypothetical projects (labeled $A$ through $E$ ) in the environmental review process as of a given date. For Figure 3.2, that date is June 1989. The most recently completed step is shown to the left of that point; major future steps are projected to the right. With so many projects shown on the integrated timechart, some of the detail of the individual project timecharts must be sacrificed. For example, if a project or activity progresses to a decision point such as the threshold question, the process shown on Figure 3.2 stops and alternative branches are not projected. The uncertainty intervals have not been included; therefore, the times indicated must be regarded as very approximate. This is a tool to give a rough overall picture of current and near-term future environmental documentation being prepared on the Hanford Site. The Integrated Project Timechart is divided into three parts:

- Other Environmental Documentation. This includes all projects currently in the process of an EE, ADM, or awaiting a decision (e.g., on a threshold question) following the completion of either of these documents. 


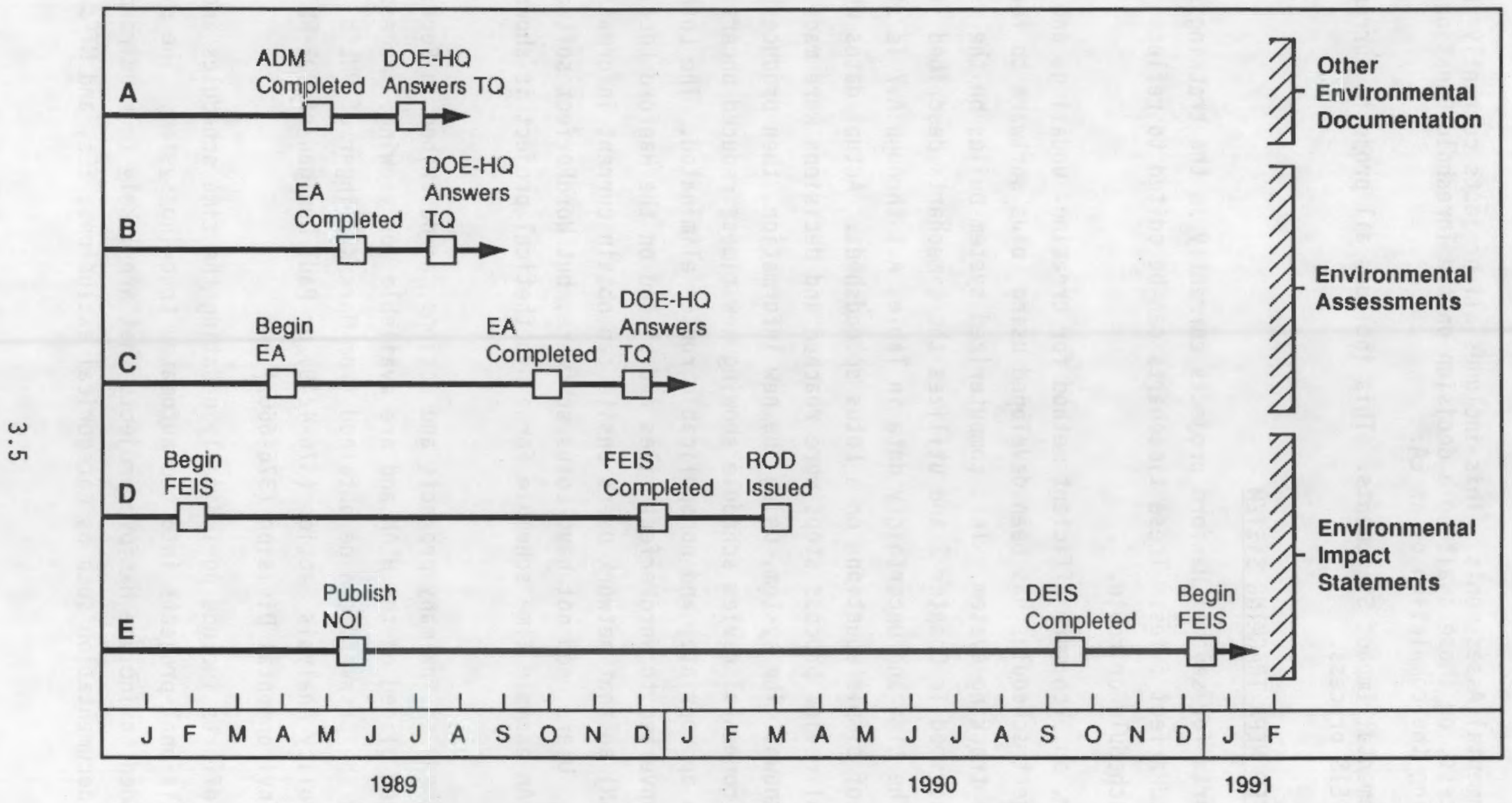

FIGURE 3.2. Conceptual Integrated Timechart 
- Environmental Assessments. This includes all projects currently in the EA process, or those awaiting a decision on the Threshold Question following the completion of an EA.

- Environmental Impact Statements. This includes all projects currently in the EIS process.

\subsection{AUTOMATED NEPA TRACKING SYSTEM}

Timecharts for several Hanford projects currently in the tracking system exist in WordPerfect files. These timecharts can be edited to reflect updates in schedule or route.

However, an even more efficient method for creating, updating, and viewing project schedules has been developed using Lotus software to further automate the tracking system. This computerized system builds on the approach described in Chapter 2 and utilizes the timecharts described in Chapter 3. The time and uncertainty data in Tables A.1 through A.7 is stored in the form of simple equations on a Lotus spreadsheet. Actual dates when environmental review process steps were reached and decisions were made are input when known. The system, using the new information, then produces an updated environmental review schedule showing new times, reduced uncertainty intervals as appropriate, and nonapplicable routes eliminated. The Lotus files are converted to WordPerfect files and placed on the Hanford Local Area Network (HLAN) so that network users onsite can obtain current information on any project. Users need not have Lotus software, but WordPerfect software is necessary. An example time schedule for a hypothetical project is shown in Figure 3.3 .

Time schedules for many projects and actions, as described in Section 3.1, have been placed on the HLAN and are available for viewing. Access commands and the password can be obtained from Mark Killinger of PNL'S Technology Policy Analysis Section (376-4249) or Paul Dunigan of DOE-RL's Safety and Environmental Division (376-6667).

Future efforts include periodically updating the time schedules and entering additional projects into the automated tracking system. The system may be expanded to include Hanford projects that are likely to require only lower-level documentation such as categorical exclusions, EEs, and MTFs. The 
HANFORD SITE IMPLEMENTATION OF NEPA: ACTIVITIES TRACKING SYSTEM

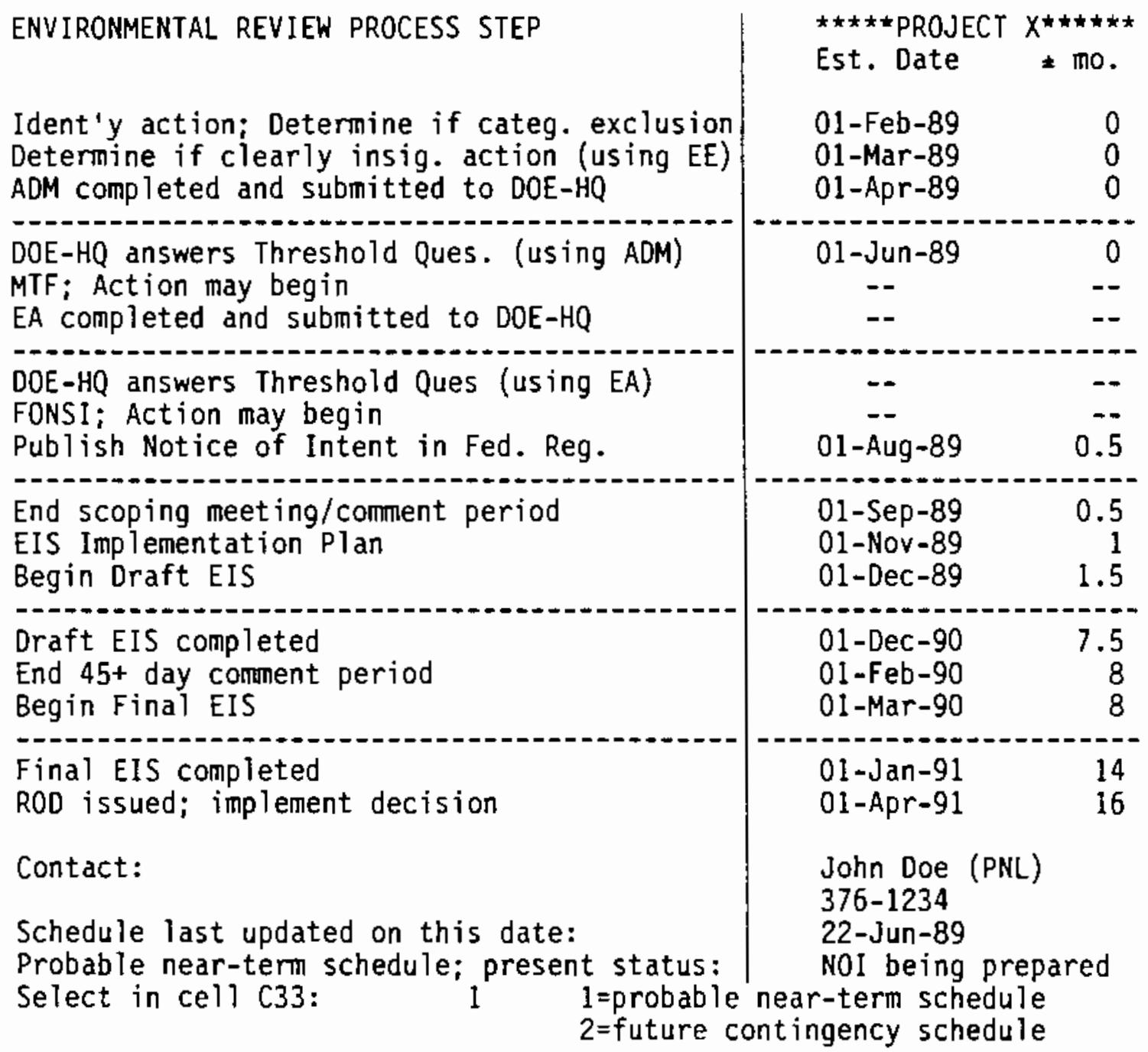

Comments :

FIGURE 3.3. Time Schedule from Automated Tracking System 
system may also be used to perform trending analyses on the amount of time required to complete various steps of the environmental review process. 


\subsection{REFERENCES}

Council on Environmental Quality (CEQ). 1986. Regulations for Implementing the Procedural Provisions of the National Environmental Policy Act. Reprint of 40 CFR 1500-1508 as of July 1 , 1986, U.S. Government Printing Office, Washington, D.C.

King, S. E. 1989. Guidelines for Hanford Site Implementation of the National Environmental Policy Act. PNL-6755, Pacific Northwest Laboratory, Richland, Washington.

U.S. Department of Energy (DOE). 1987. "DOE NEPA Guidelines." 52 Federal Register 47663, December 15, 1987.

U.S. Department of Energy, Richland Operations Office (DOE-RL). 1987. "Implementation of the National Environmental Policy Act at the Richland Operations 0ffice." O0E-RL Order 5440.1A. 
APPENDIX A

IIME AND UNCERTAINTY INTERVALS 
APPENDIX A

\section{TIME AND UNCERTAINTY INTERVALS}

This appendix contains seven tables showing time and uncertainty intervals used in developing the project timecharts. Each table corresponds to a route on the GERF (Figure 2.1). The times in the tables are based on past Hanford Site experience and on discussions with knowledgeable PNL personnel. Some time intervals actually used on the timecharts differ somewhat from the following tables. This difference occurs because specific completion schedules for certain documents have already been established by the personnel involved. In those cases, their projections are used for the timechart. In addition, some projects may have special deadlines which result in certain requirements on the completion of environmental documentation.

In the tables, answers to questions and other determinations (e.g., the threshold question) are given in brackets.

The process step "EIS Implementation Plan" is defined as the point when the EIS Implementation Plan is sufficiently completed to allow the DEIS to begin. Development of the Plan may continue while the DEIS is being written. 
TABLE A.1. Time and Uncertainty Intervals for Route 1

\begin{tabular}{|c|c|c|}
\hline $\begin{array}{l}\text { Step } \\
\text { (for Route 1: } \quad \text { Categorical Exclusion) }\end{array}$ & $\begin{array}{l}\text { Est. months to } \\
\text { complete step }\end{array}$ & $\begin{array}{l}\text { Imo. } \\
\text { (uncert. } \\
\text { interval) }\end{array}$ \\
\hline Ident'y action; Det. if categ. exclusion [Yes] & $t$ & 0 \\
\hline MTF; Action may begin & $\underline{1}$ & 0.5 \\
\hline Total & 1 & \pm 0.5 \\
\hline
\end{tabular}

TABLE A.2. Time and Uncertainty Intervals for Route 2

\begin{tabular}{l} 
(for Route 2: Clearly Insig. Action) \\
\hline Ident'y action; Det. if categ. exclusion [No] \\
Det. if clearly insig. action (using EE) [Yes] \\
MTF; Action may begin \\
Total
\end{tabular}

\begin{tabular}{|c|c|}
\hline $\begin{array}{l}\text { Est. \# months to } \\
\text { complete step }\end{array}$ & $\begin{array}{l} \pm \text { mo. } \\
\text { (uncert. } \\
\text { interval) }\end{array}$ \\
\hline$t$ & 0 \\
\hline 1 & 0.5 \\
\hline$\underline{1}$ & 0.5 \\
\hline 2 & \pm 1 \\
\hline
\end{tabular}

IABLE A.3. Time and Uncertainty Intervals for Route 3

\begin{tabular}{|c|c|c|}
\hline $\begin{array}{c}\text { Step } \\
\text { (for Route 3: ADM/MTF) }\end{array}$ & $\begin{array}{l}\text { Est. months to } \\
\text { complete step } \\
\end{array}$ & $\begin{array}{l} \pm \text { mo. } \\
\text { (uncert. } \\
\text { interval) }\end{array}$ \\
\hline Ident'y action; Det. if categ. exclusion [No] & $\mathrm{t}$ & 0 \\
\hline Det. if clearly insig. action (using $E E$ ) [No] & 1 & 0.5 \\
\hline ADM completed and submitted to DOE-HQ & 1 & 0.5 \\
\hline DOE-HQ answers Threshold Ques. [No] & 2 & 1 \\
\hline MTF; Action may begin & $\underline{1}$ & 0.5 \\
\hline Total & 5 & \pm 2.5 \\
\hline
\end{tabular}


TABLE A.4. Time and Uncertainty Intervals for Route 4

\section{Step \\ (for Route 4: ADM/EA/FONSI)}

Ident'y action; Det. if categ. exclusion [No]

Det. if clearly insig. action (using EE) [No]

ADM completed and submitted to DOE-HQ

DOE-HQ answers Threshold Ques. [?]; begin EA

EA completed and submitted to DOE-HQ

DOE-HQ answers Threshold Ques. [No]

FONSI; Action may begin

Total

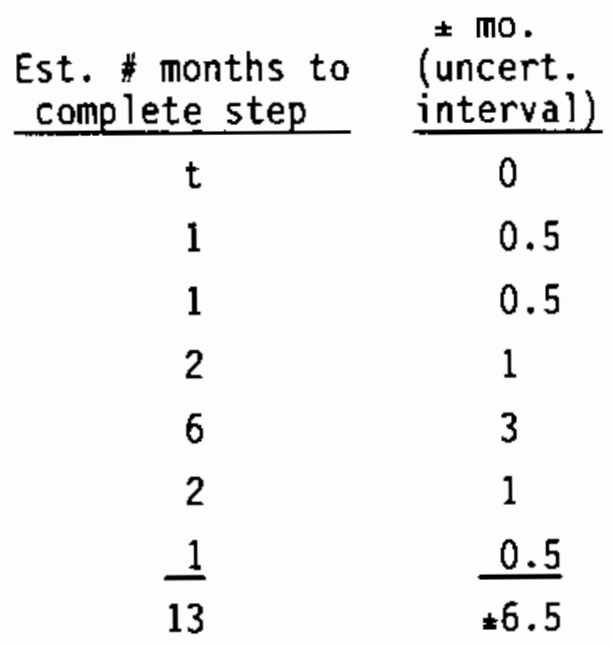

TABLE A.5. Time and Uncertainty Intervals for Route 5

Step

(for Route 5: ADM/EIS)

Ident'y action; Det. if categ. exclusion [No]

Det. if clearly insig. action (using EE) [No]

ADM completed and submitted to DOE-HQ

DOE-HQ answers Threshold Ques. [Yes]

Publish Notice of Intent in Fed. Reg.

End scoping meeting/comment period

EIS Implementation Plan

Begin Draft EIS

Draft EIS completed

End $45+$ day comment period

Begin Final EIS

Final EIS completed

ROD issued; implement decision

Total =mo.

Est. \# months to (uncert. complete step interval)

t

0

0.5

1

0.5

2

1

0.5

1

0

0.5

0.5

6

0.5

0

10

6

3

38
2

$\pm 18$ 
TABLE A.6. Time and Uncertainty Intervals for Route 6

Step

(for Route 6: ADM/EA/EIS)

Ident'y action; Det. if categ. exclusion [No]

Det. if clearly insig. action (using $E E$ ) [No]

ADM completed and submitted to DOE-HQ

DOE-HQ answers Threshold Ques. [?]; begin EA

EA completed and submitted to DOE-HQ

DOE-HQ answers Threshold Question [Yes]

Publish Notice of Intent in Fed. Reg.

End scoping meeting/comment period

EIS Implementation PIan

Begin Draft EIS

Draft EIS completed

End $45+$ day comment period

Begin Final EIS

Final EIS completed

ROD issued; implement decision Total

Est. \# months to (uncert. complete step intervai)

$\mathrm{t}$

1

1

2

6

2

2

1

2

1

12

2

1

10

$\frac{3}{46}$
0

0.5

0.5

1

3

1

0.5

0

0.5

0.5

6

0.5

0

6

$\frac{2}{22}$ 
TABLE A.7. Time and Uncertainty Intervals for Route 7

Step

(for Route 7: EIS)

Ident'y action; Det. if categ. exclusion [No]

ADM completed and submitted to DOE-HQ

Publish Notice of Intent in Fed. Reg.

End scoping meeting/comment period

EIS Implementation Plan

Begin Draft EIS

Draft EIS completed

End $45+$ day comment period

Begin Final EIS

Final EIS completed

ROD issued; implement decision

Total
Est. \# months to complete step

$t$

I

2

1

2

1

12

2

1

10

$\frac{3}{35}$

35 \pm mo. (uncert. interval) 0 0.5

0.5

0

0.5

0.5

6

0.5

0

6

2

$\pm 16.5$ 


\section{DISTRIBUTION}

No. of

Copies

\section{OFFSITE}

2 DOE/Office of Scientific and Technical Information

C. M. Borgstrom

Office of NEPA Project Assistance, EH-25

U.S. Department of Energy Washington, DC 20545

\section{ONSITE}

29 DOE Richland Operations Office

M. J. Anthony

E. A. Bracken

R. M. Carosino

P. F. Dunigan (10)

0 . A. Farabee

R. D. Freeberg

R. E. Gerton

J. D. Goodenough

R. G. Hastings

R. A. Holten

J. R. Hunter

R. D. Izatt

M. S. Karol

J. J. Keating

J. E. Rasmussen

A. J. Rizzo

D. M. Smith

M. W. Tiernan

D. E. Trader

L. C. Williams

6 Westinghouse Hanford Company

L. C. Brown

C. Defigh-Price

C. J. Geier

M. T. Jansky

R. E. Lerch

H. E. McGuire
No. of

Copies

Kaiser Engineering Hanford

W. H. Bodily

Hanford Environmental Health Foundation

L. J. Maas

100 Pacific Northwest Laboratory

R. C. Adams

W. J. Bair

R. W. Bienert

T. D. Chikalla

J. M. Davidson

J. W. Falco

C. A. Geffen (10)

M. S. Hanson

D. G. Huizenga

M. H. Killinger (45)

S. E. King

J. F. Keller

P. J. Mellinger

E. B. Moore

I. C. NeTson

R. L. Newell

J. V. Robinson

K. B. Selby (3)

A. K. Stalker (7)

S. L. Stein

G. M. Stokes

J. L. Straaslund

B. R. Stults

W. L. Templeton (10)

Publishing Coordination

Technical. Report Files 
